of patients in the liposomal prednisone groups reported AEs related to study drug administration, versus $6 \%$ in the methylprednisolone group. Serious adverse events (SAEs) were reported by 4 (8.2\%), 1 (1.9\%) and 2 patients (4.1\%) resp for the liposomal prednisone $75 \mathrm{mg}$, liposomal prednisone $150 \mathrm{mg}$ and methylprednisolone $120 \mathrm{mg}$ groups. Five of the 7 SAEs were treatment related; these included 4 events of hypersensitivity in the liposomal prednisone arms and one event of viral upper respiratory tract infection in the methylprednisolone group.

Conclusion: In this phase III trial, liposomal prednisone $75 \mathrm{mg}$ and 150 $\mathrm{mg}$ were significantly more effective than $120 \mathrm{mg}$-methylprednisolone in treating patients with a flare of their RA. The overall incidence of AEs was similar across treatment groups, although hypersensitivity appeared to be more common with liposomal prednisone.

Disclosure of Interests: Johannes WJ Bijlsma Grant/research support from: The department of the author who included patients (JWJB) in the U-Act-Early trial received reimbursements from Roche Nederland BV. JWJB reported grants and fees from Roche, AbbVie, Bristol-Myers Squibb, Merck Sharp \& Dohme, Pfizer, and UCB

University Medical Center Utrecht, Utrecht University, Consultant for: SUN Pharma, Speakers bureau: Lilly, Roche, Bart Metselaar Shareholder of: Enceladus, Grant/research support from: SUN Pharma, Leonie Middelink Grant/research support from: SUN Pharma, Cees Wortel Shareholder of: Enceladus, Accelovance, Grant/research support from: SUN Pharma, Consultant for: SUN Pharma, Reinhard Bos Grant/research support from: SUN Pharma, Jacob M. van Laar Grant/research support from: Genentech, Consultant for: F. Hoffmann-La Roche, Harald Vonkeman: None declared, Rene Westhovens Grant/research support from: Bristol-Myers Squibb, Consultant for: Celltrion, Galapagos-Gilead, Siu Long Yao Shareholder of: SUN Pharma, Employee of: SUN Pharma, Mudgal Kothekar Shareholder of: SUN Pharma, Employee of: SUN Pharma, Atul Raut Shareholder of: SUN Pharma, Employee of: SUN Pharma DOI: 10.1136/annrheumdis-2019-eular.4052

\section{FRI0136 THE EFFICACY AND SAFETY OF SIROLIMUS IN PATIENTS WITH ACTIVE RHEUMATOID ARTHRITIS: A RANDOMIZED AND PARALLEL-CONTROLLED CLINICAL TRIAL}

Jia Wang ${ }^{1}$, Sheng-xiao Zhang ${ }^{1}$, Fang Yuan $\mathrm{Hu}^{1}$, Xiao-Juan Zheng ${ }^{1}$, Ting Cheng ${ }^{1}$, $\mathrm{Na}-\mathrm{Na} \mathrm{Yu}{ }^{1}$, Wen-Xian Yang ${ }^{1}$, Chong Gao ${ }^{2}$, Hong-Yan Wen ${ }^{1}$, LI Xiao-Feng ${ }^{1}$. ${ }^{1}$ The Second Hospital of Shanxi Medical University, Department of Rheumatology, Taiyuan, China; ${ }^{2}$ Brigham and Women's Hospital, Harvard Medical School, Department of Pathology, Boston, United States of America

Background: We have reported previously that the insufficient absolute number or functional defects of regulatory $T$ cells (Tregs) in patients with rheumatoid arthritis (RA) ${ }^{[1-3]}$, challenging conventional unspecific immunosuppressive therapy. Sirolimus, a mTOR inhibitor, is reported to allow growth of functional Tregs, which would be able to provide new strategy and target for the treatment of $\mathrm{RA}^{[4]}$.

Objectives: To investigate efficacy and safety of sirolimus combined with conventional immunosuppressants for RA treatment.

Methods: In this non-blinded and parallel-group trial, we randomly assigned 62 patients to receive conventional glucocorticoids and immunosuppressants with or without sirolimus at a dosage of $0.5 \mathrm{mg}$ on alternate days for 24 weeks in a 2:1 ratio. The demographic features, clinical manifestations and laboratory indicators including peripheral blood lymphocyte subgroups and $\mathrm{CD}^{+} \mathrm{T}$ subsets were compared before and after the treatment.

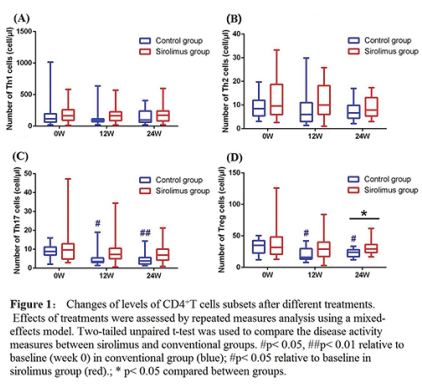

Results: Finally, 37 patients in sirolimus group and 18 in conventional treated group completed 6-month study. By 24 weeks, the patients with sirolimus experienced the significant reduction in disease activity indicators including DAS28, ESR, the number of tender joints and swollen joints $(p<0.001)$. Notably, they had a higher level of Tregs as compared those with conventional therapy alone $(p<0.05)$, indicating that sirolimus could partly restore the reduced Tregs. Concomitantly, their usages of immunosuppressants for controlling disease activity were decreased as compared with conventional group with no difference in blood routine, liver and renal functions both before and after the treatment of sirolimus and between two groups $(p>0.05)$.

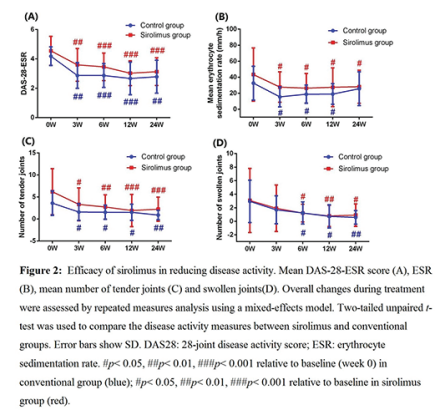

Conclusion: Low-dose sirolimus immunoregulatory therapy selectively upregulated Tregs and partly replaced the usage of immunosuppressants to control disease activity without over-treatment and evaluable side effect The further study is required using a large sample of RA patients treated with sirolimus for longer period.

\section{REFERENCES}

[1] Komatsu N, Takayanagi $\mathrm{H}$. Arthritogenic T cells in autoimmune arthritis[J]. The international journal of biochemistry \& cell biology, 2015, 58:92-96. doi:10.1016/j.biocel.2014.11.008.

[2] Morita T, Shima Y, Wing JB, et al. The Proportion of Regulatory T Cells in Patients with Rheumatoid Arthritis: A Meta-Analysis[J]. PloS one, 2016, 11 (9):e0162306.doi:10.1371/journal.pone.0162306.

[3] Spence A, Klementowicz JE, Bluestone JA, et al. Targeting Treg signaling for the treatment of autoimmune diseases[J]. Current opinion in immunology, 2015, 37:11-20.doi:10.1016/j.coi.2015.09.002.

[4] Perl A. Activation of mTOR (mechanistic target of rapamycin) in rheumatic diseases[J]. Nature reviews Rheumatology, 2016, 12(3):169-182. doi:10.1038/nrrheum.2015.172

Acknowledgement: No

Disclosure of Interests: None declared

DOI: 10.1136/annrheumdis-2019-eular.3906

\section{FRI0137 UPADACITINIB IMPROVES PATIENT-REPORTED OUTCOMES IN PATIENTS WITH RHEUMATOID ARTHRITIS AND INADEQUATE RESPONSE TO METHOTREXATE: RESULTS FROM SELECT-COMPARE}

Vibeke Strand ${ }^{1}$, Martin Bergman ${ }^{2}$, Namita Tundia $^{3}$, Andrew Ostor ${ }^{4}$, Patrick Durez ${ }^{5}$, In-Ho Song ${ }^{3}$, Jose Jeffrey Enejosa ${ }^{3}$, Casey Schlacher ${ }^{3}$, Yan Song ${ }^{6}$,

Roy Fleischmann ${ }^{7}$. ${ }^{1}$ Stanford University, Palo Alto, CA, United States of America;

${ }^{2}$ Drexel University College of Medicine, Philadelphia, PA, United States of America ${ }^{3}$ AbbVie Inc., North Chicago, IL, United States of America; ${ }^{4}$ Cabrini Medical Centre, Monash University, Melbourne, Australia; ${ }^{5}$ Université Catholique de Louvain and Cliniques Universitaires Saint-Luc, Brussels, Belgium; ${ }^{6}$ Analysis Group Inc., Boston, MA, United States of America; ${ }^{7}$ University of Texas Southwestern Medical Center, MCRC Center, Dallas, TX, United States of America

Background: Upadacitinib (UPA), a selective JAK1 inhibitor, has demonstrated superior improvement in the clinical signs and symptoms of rheumatoid arthritis (RA) compared with placebo (PBO) and adalimumab (ADA). ${ }^{1}$

Objectives: To evaluate the effect of UPA vs PBO and vs ADA on patient-reported outcomes (PROs) at Week 12 in SELECT-COMPARE (NCT02629159), a randomised controlled trial (RCT) in an active RA population with inadequate responses to methotrexate (MTX).

Methods: Patients in SELECT-COMPARE, a phase $3 \mathrm{RCT}$, received UPA (15 mg once daily), PBO, or ADA (40 mg every other week) while on background MTX therapy. The following PROs were collected prospectively: Patient Global Assessment of Disease Activity (PtGA) by visual analogue scale (VAS), pain by VAS, Health Assessment Questionnaire Disability Index (HAQ-DI), duration and severity of morning (AM) stiffness, health-related quality of life by Short Form-36 (SF-36), Functional Assessment of Chronic Illness Therapy-Fatigue (FACIT-F), and Work Instability Scale for RA (RA-WIS). Least squares mean (LSM) changes from baseline $(B L)$ to Week 12 were based on mixed-effects repeated measures 
models. The proportions of patients reporting improvements $\geq$ minimum clinically important differences (MCID) from $\mathrm{BL}$ to Week 12 or scores $\geq$ normative values were determined with UPA, PBO, and ADA treatment; comparisons used chi-square tests.

Results: Data from 1629 patients (UPA: 651; PBO: 651; ADA: 327) were analysed. Mean age was 54 years; $79 \%$ were female; $54 \%$ had RA for $\geq 5$ years. Baseline mean PRO scores were similar across treatment groups. At Week 12, UPA treatment resulted in statistically significant LSM changes from BL vs PBO across all PROs and statistically significant LSM changes from BL vs ADA in PtGA, pain, HAQ-DI, AM stiffness severity, FACIT-F, and SF-36 physical component summary (PCS) and 6/ 8 domain scores (Table). ADA treatment resulted in statistically significant LSM changes from baseline vs PBO in PtGA, pain, HAQ-DI, AM stiffness severity and duration, FACIT-F, and SF-36 PCS and 5/8 domain scores. Compared with $\mathrm{PBO}$ at Week 12, significantly more UPA-treated patients reported improvements $\geq \mathrm{MCID}$ and scores $\geq$ normative values across all PROs with numbers needed to treat (NNTs) $<10$. The proportions of UPA-treated patients reporting improvements $\geq$ MCID were similar or numerically higher than ADA-treated patients. Importantly, the proportion of UPA vs ADA treated patients reporting improvements $\geq$ normative values were significantly greater (all $p<0.05$ ) in PtGA (36\% vs $26 \%$ ), HAQDI $(21 \%$ vs $14 \%)$, SF-36 PCS $(16 \%$ vs $11 \%)$, and SF-36 bodily pain $(29 \%$ vs $21 \%)$ and vitality $(42 \%$ vs $35 \%)$ domains.

\begin{tabular}{|c|c|c|c|c|c|c|c|}
\hline \multicolumn{8}{|c|}{ LSM Changes from Baseline and Percentage of Responders at Week 12 After UPA Initiation } \\
\hline \multirow[b]{2}{*}{ PRO } & \multirow{2}{*}{$\begin{array}{c}\begin{array}{c}\text { Baseline } \\
\text { Mean }\end{array} \\
\text { (n=1629) }\end{array}$} & \multicolumn{3}{|c|}{ LSM Changes from Baseline } & \multicolumn{3}{|c|}{$\begin{array}{l}\text { Patients Reporting Improvements } \\
\qquad M C I D, n(\%)\end{array}$} \\
\hline & & $\begin{array}{l}\text { UPA } 15 \mathrm{mg} \\
(\mathrm{n}=651)\end{array}$ & $\begin{array}{c}\text { PBO } \\
(n=651)\end{array}$ & $\begin{array}{l}\text { ADA } 40 \mathrm{mg} \\
(\mathrm{n}=327)\end{array}$ & $\begin{array}{l}\text { UPA } 15 \mathrm{mg} \\
\qquad(\mathrm{n}=651)\end{array}$ & $\begin{array}{c}\text { PBO } \\
\text { (n=651) }\end{array}$ & $\begin{array}{c}\text { ADA } 40 \mathrm{mg} \\
(\mathrm{n}=327)\end{array}$ \\
\hline PtGA & 64.4 & $-30.4^{* 5}$ & -15.2 & $-23.6^{x}$ & $474(73.4)^{*}$ & $332(51.1)$ & $219(67.6)$ \\
\hline Pain VAS & 65.5 & $-31.8^{* 5}$ & -15.5 & $-25.3^{x}$ & $483(74.8)^{*}$ & $347(53.4)$ & $227(69.8)$ \\
\hline HAQ-DI & 1.6 & $-0.6^{* 5}$ & -0.3 & $-0.5^{x}$ & $465(72.1)^{*}$ & $330(50.8)$ & $231(71.1)$ \\
\hline FACIT-F & 26.8 & $9.0 * 5$ & 4.8 & $7.4^{7}$ & $413(64.0)^{*}$ & $299(46.4)$ & $202(62.2)$ \\
\hline $\begin{array}{l}\text { Duration AM } \\
\text { Stiffness }\end{array}$ & 142.8 & $-92.6^{*}$ & -48.6 & $-82.7^{*}$ & $194(29.9)^{\mathrm{b} *}$ & $144(22.1)$ & $93(28.7)^{\mathrm{b}}$ \\
\hline $\begin{array}{l}\text { Severity AM } \\
\text { Stiffness }^{c}\end{array}$ & 6.3 & $-3.4^{* 5}$ & -1.8 & $-2.9^{x}$ & $526(81.3)^{0 *}$ & $424(65.0)$ & $260(80.2)^{\circ}$ \\
\hline RA-WIS & 14.7 & $-5.2^{*}$ & -2.0 & $-4.5^{x}$ & $120(41.7)^{*}$ & $64(24.4)$ & $42(32.1)$ \\
\hline SF-36 PCS & 32.5 & $7.9 * 5$ & 3.6 & $6.3^{x}$ & $469(72.5)^{*}$ & $345(53.2)$ & $226(69.1)$ \\
\hline SF-36 MCS & 42.9 & $6.4^{*}$ & 3.7 & 5.4 & $386(59.7)^{*}$ & $309(47.7)$ & $192(58.7)$ \\
\hline SF-36 PF & 31.5 & $7.3^{* 5}$ & 3.6 & $6.2^{x}$ & $479(73.7)^{*}$ & $379(58.2)$ & $237(72.5)$ \\
\hline SF-36 RP & 33.3 & $6.9^{* 5}$ & 3.6 & 5.2 & $470(72.3)^{* 5}$ & $374(57.5)$ & $213(65.1)$ \\
\hline SF-36 BP & 34.1 & $9.9^{* 5}$ & 4.6 & $8.0^{*}$ & 501 (77.1)* & $390(59.9)$ & $239(73.1)$ \\
\hline SF-36 GH & 37.8 & $7.3^{* 5}$ & 3.1 & $5.7^{x}$ & $458(70.5)^{*}$ & $362(55.6)$ & $212(64.8)$ \\
\hline SF-36VT & 40.9 & $8.2^{25}$ & 4.3 & $6.8^{x}$ & $479(73.7)^{*}$ & $372(57.1)$ & $225(68.8)$ \\
\hline SF-36 SF & 38.1 & $7.2^{* 5}$ & 3.4 & $5.8^{x}$ & $418(64.3)^{*}$ & $323(49.6)$ & $195(59.6)$ \\
\hline SF-36 RE & 37.9 & $6.2^{*}$ & 3.6 & 5.2 & $368(56.6)^{*}$ & $301(46.2)$ & $175(53.5)$ \\
\hline SF-36 MH & 40.7 & $7.0^{*}$ & 4.0 & 5.9 & $449(69.1)^{*}$ & 349 (53.6) & $213(65.1)$ \\
\hline 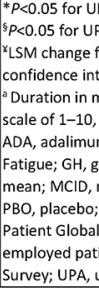 & 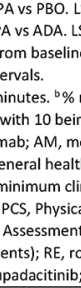 & $\begin{array}{l}\text { responders rep } \\
\text { g the worst le } \\
\text { orning; BP, boc } \\
\text { h; HAQ-DI, Hea } \\
\text { nically importa } \\
\text { al Component } \\
\text { t of Disease Ac } \\
\text { ole emotional; } \\
\text {; VAS, visual an }\end{array}$ & $\begin{array}{l}\text { orting score } \\
\text { el. } \\
\text { ily pain; FA } \\
\text { th Assessm } \\
\text { tt differenc } \\
\text { ummary; } P \\
\text { ivity; RA-W } \\
\text { P, role phy } \\
\text { logue scale }\end{array}$ & $\begin{array}{l}\text { IT-F, Function } \\
\text { ent Questionn } \\
\text {; MCS, Ment } \\
\text { physical fun } \\
\text { S, Work Instat } \\
\text { ical; SF, social } \\
\text {;VT, vitality. }\end{array}$ & $\begin{array}{l}\text { ortant differen } \\
\text { Assessment o } \\
\text { ire Disability In } \\
\text { Component Su } \\
\text { ion; PRO, patie } \\
\text { ity Scale for Rh } \\
\text { unction; SF-36, }\end{array}$ & $\begin{array}{l}\text { 'Assessed o } \\
\text { hronic Illness } \\
\text { x; LSM, least } \\
\text { nary; MH, me } \\
\text {-reported out } \\
\text { imatoid Arthr } \\
\text {;-ltem Short }\end{array}$ & $\begin{array}{l}\text { en groups. } \\
\text { in groups. } \\
\text { ping 95\% } \\
\text { a numeric } \\
\text { Therapy- } \\
\text { quares } \\
\text { tala health; } \\
\text { ome; PtGA, } \\
\text { is (among } \\
\text { orm Health }\end{array}$ \\
\hline
\end{tabular}

Conclusion: Among patients with active RA, treatment with UPA $15 \mathrm{mg}$ QD on background MTX therapy for 12 weeks resulted in statistically significant and clinically meaningful improvements in PROs compared with PBO. Overall, PRO improvements with UPA treatment met or were superior to treatment with $A D A$, especially in key domains of pain, function and vitality.

\section{REFERENCES:}

[1] Fleischmann R, et al. Arthritis Rheumatol. 2018;70(S9), abstract 890.

Acknowledgement: AbbVie sponsored the study and contributed to the design, analysis and interpretation of data. Medical writing services were provided by Brandy Menges of JK Associates Inc. and were funded by AbbVie.

Disclosure of Interests: Vibeke Strand Consultant for: AbbVie, Amgen, Bayer, BMS, Boehringer Ingelheim, Celgene, Celltrion, CORRONA, Crescendo, EMD Serono, Genentech/Roche, GSK, Horizon, Inmedix, Janssen, Kezar, Lilly, Merck, Novartis, Pfizer, Regeneron, Samsung, Sandoz, Sanofi, Servier, UCB., Martin Bergman Shareholder of: Johnson and Johnson (parent company of Janssen), Consultant for: AbbVie, Amgen, BMS, Celgene, Genentech/Roche, Janssen, Merck, Novartis, Pfizer, and Sanofi/Regeneron, Speakers bureau: AbbVie, Amgen, BMS, Celgene, Genentech/Roche, Janssen, Merck, Novartis, Pfizer, and Sanofi/Regeneron, Namita Tundia Shareholder of: AbbVie, Employee of: AbbVie, Andrew Ostor Consultant for: AbbVie, BMS, Roche, Janssen, Lilly, Novartis, Pfizer, UCB, Gilead, Paradigm, Patrick Durez Speakers bureau: BMS, Lilly, Sanofi, and Celltrion, In-Ho Song Shareholder of: AbbVie Inc Employee of: AbbVie Inc, Jose Jeffrey Enejosa Shareholder of: AbbVie Inc, Employee of: AbbVie Inc, Casey Schlacher Shareholder of: AbbVie, Employee of: AbbVie, Yan Song Employee of: Analysis Group Inc., which received consulting fees from AbbVie for this study, Roy Fleischmann Grant/research support from: AbbVie, Amgen, AstraZeneca, Bristol-Myers Squibb, Celtrion, Genentech, GSK, Janssen, Lilly, Novartis, Pfizer Inc Sanofi-Aventis, UCB, Consultant for: AbbVie, Amgen, AstraZeneca, BristolMyers Squibb, Celtrion, Genentech, GSK, Janssen, Lilly, Novartis, Pfizer Inc, Sanofi-Aventis, UCB

DOI: 10.1136/annrheumdis-2019-eular.287

\section{FRI0138 EXPOSURE-RESPONSE ANALYSES OF UPADACITINIB EFFICACY AND SAFETY IN RHEUMATOID ARTHRITIS - ANALYSES OF PHASE 2 AND 3 STUDIES}

Mohamed-Eslam Mohamed ${ }^{1}$, Ahmed Nader ${ }^{1}$, Insa Winzenborg ${ }^{2}$, Eva Doelger ${ }^{2}$, Peter Noertersheuser ${ }^{2}$, Aileen Pangan ${ }^{1}$, Ahmed Othman ${ }^{1} .{ }^{1}$ AbbVie, North Chicago, United States of America; ${ }^{2} A b b$ Vie Deutschland GmbH and Co. KG, Ludwigshafen, Germany

Background: Upadacitinib (UPA), an oral selective JAK1 inhibitor, demonstrated favorable efficacy and acceptable safety in two Phase 2 and five Phase 3 global studies in subjects with moderately to severely active rheumatoid arthritis (RA).

Objectives: To characterize relationships between UPA plasma exposures and different efficacy and safety endpoints using data from Phase 2 and Phase 3 RA studies.

Methods: Analyses were conducted using data from 3685 (for efficacy) and 4577 (for safety) subjects with RA enrolled in the Phase 2 and 3 studies. Relationships between UPA plasma concentrations and efficacy and selected clinically relevant safety endpoints were analyzed using Markov Chain models and logistic regression analyses, respectively.

Results: Percentage of subjects achieving ACR20, ACR50, AC70, DAS28 $(\mathrm{CRP}) \leq 3.2$, and DAS28(CRP) $<2.6$ increased with increasing UPA exposures, with maximum efficacy reached at exposures of $15 \mathrm{mg}$ to 30 $\mathrm{mg}$ QD. Model-estimated efficacy responses are presented in Table 1. No relationships were observed between UPA exposure and pneumonia, herpes zoster infection, changes in platelet count (platelets $\geq 600 \times 10^{9} / \mathrm{L}$, platelets $>400 \times 10^{9} / \mathrm{L}$ ), lymphopenia (Grade 4 or higher), and neutropenia (Grade 3 or higher) at Week $12 / 14$ or Week 24/26. Shallow trends for exposure-response relationships were observed for $>2 \mathrm{~g} / \mathrm{dL}$ decrease in hemoglobin from baseline at Week $12 / 14$ and Week 24/26, lymphopenia Grade 3 or higher at Week 12/14, and serious infections at Week 24/26 No relationship with UPA exposure was observed for Grade 3 or higher lymphopenia at Week 24/26 (Figure 1).

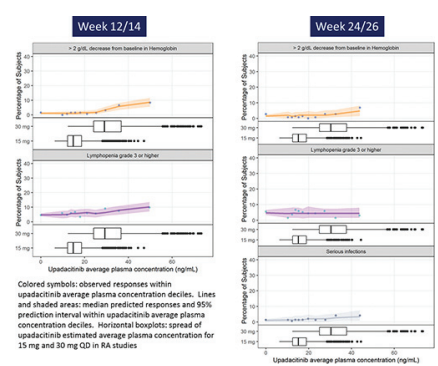

Figure 1. Observed and Model Predicted Percentage of Subjects Experiencing Laboratory Changes/Safety Events of Interest with Increasing UPA Plasma Exposures 